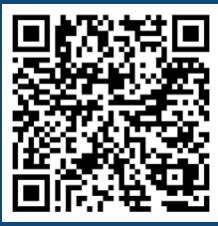

Keywords:

Micropropagation Gas exchange Porous membrane

Historic: Received 15/04/2019 Accepted 10/07/2019

Correspondence: gilvano.brondani@ufla.br
Denys Matheus Santana Costa Souzala+, Sérgio Bruno Fernandes ${ }^{\mathrm{lb}}$, Maria Lopes Martins Avelarlc, Samira Rangel do Prado Frade ${ }^{l d}$, Letícia Vaz Molinarile, Douglas Santos Gonçalves If, Gilvano Ebling Brondanilg

\title{
MIXOTROPHISM EFFECT ON IN VITRO ELONGATION AND ADVENTITIOUS ROOTING OF Eucalyptus dunnii
}

SOUZA, D. M. S. C.; FERNANDES, S. B; AVELAR, M. L. M.; FRADE, S. R; P.; MOLINAR, L. V; GONÇALVES, D. S.; BRONDANI, G. E. Mixotrophism effect on in vitro elongation and adventitious rooting of Eucalyptus dunnii. CERNE, v. 25, n. 4, p.394-40I, 2019.

\section{HIGHLIGHTS}

Different types of sealing and sucrose concentrations influence in vitro elongation and adventitious rooting.

Higher gas exchange $\left(\mathrm{CO}_{2}\right)$ favors the in vitro plant growth.

The autotrophic system for the in vitro cultivation of Eucalyptus dunnii was not efficient.

\section{ABSTRACT}

The relevance of Eucalyptus dunnii has been evidenced mainly for its wood quality and cold tolerance among cultivated subtropical eucalypts. However, rooting is a challenge for its propagation, particularly when adult material is involved. This study aimed to assess the mixotrophism on the in vitro elongation and adventitious rooting phases in Eucalyptus dunnii microcutting. The experimental material used was obtained from a ministumps of Eucalyptus dunnii clones. In order to evaluate gas exchange and sucrose supplementation on in vitro elongation and adventitious rooting, the experiment was prepared in a $3 \times 4$ factorial arrangements with three forms of sealing (rigid polypropylene caps with no membrane $(0 / M)$, with a membrane $(I / M)$, with three membranes $(3 / M)$ and four sucrose concentrations $\left(0,10,20\right.$ and $\left.30 \mathrm{~g} \cdot \mathrm{L}^{-1}\right)$. At 30 days in the elongation phase it was evaluated (length, number of shoots per explant, oxidation, bud vigor, pigment content, leaf area and anatomy) and rooting (length, root diameter and rooting). Results show that sucrose should be added in the culture medium for in vitro elongation and can be reduced to concentrations between 10 and $20 \mathrm{~g} \cdot \mathrm{L}^{-1}$. In vitro rooting requires the use of 30 $\mathrm{g} \cdot \mathrm{L}^{-1}$ of sucrose. The use of flasks with membranes that allow gas exchange is an effective alternative to promote the in vitro elongation and adventitious rooting of Eucalyptus dunnii microcutting. 


\section{INTRODUCTION}

Eucalyptus dunnii is a subtropical climate of great importance due to its wood quality and cold tolerance among cultivated subtropical eucalyptus (Smith and Henson, 2007). However, specie rooting is a challenge in clonal propagation, particularly when adult material is involved. The rejuvenation of propagules has allowed advances on in vitro elongation and adventitious rooting phases (Trueman et al., 2018). In the search for alternatives to rooting improvement in the cloning production process, micropropagation via axillary buds proliferation has been recommended (Xavier et al., 20I3). Recently, investigation on the Eucalyptus dunnii species has increased significantly in relation to in vitro vegetative propagation (Oberschelp et al., 2015), as well as in vitro elongation (Navroski et al., 2015) and adventitious rooting (Oberschelp et al., 2015; Brondani et al., 2018).

Among micropropagation stages, in vitro elongation is primordial in obtaining sprouts for microcutting rooting, which has been performed as much under ex vitro (Xavier et al., 20I3) or in vitro (Trueman et al., 20I8) conditions. However, research for improvements in the in vitro elongation phase has been intensified, aiming to obtain microstumps. Scientific studies on this field have focused on the adequacy of protocols, on the reduction of the carbon source in the culture medium, as well as knowledge of the most efficient environment for the system (Bianchetti et al., 2017).

Controlling environmental factors such as the use of mixotrophism is considered important for in vitro morphogenetic response (Heringer et al., 2017). Generally, a positive response to micropropagation among the various factors is due to the reduction or exclusion of the sucrose source, as well as the use of porous membranes, in which the relative humidity of the bottles, characterized by the presence of water and nutrients in the plant, is reduced (Bacillus et al., 2005), thus improving its ex vitro acclimatization process (Saldanha et al., 2012; Jiménez et al., 2015; Batista et al., 2017; Tisarum et al., 2018). Silva et al. (2017) reported its positive effect in different species, besides the possibility of variations in the concentration of sucrose, which benefits the cultivation and reduces expenses.

Seeking to optimize a protocol for micropropagation of Eucalytpus dunnii in the clones production process, this study aimed to assess mixotrophism on in vitro elongation and adventitious rooting phases.

\section{MATERIALS AND METHODS}

\section{Study and experimental material location}

The experiments were conducted at the Laboratory of In Vitro Culture of Forest Species,
Department of Forestry Sciences (DCF), Federal University of Lavras - UFLA, Lavras, MG. The genetic material used to obtain the explants came from microstumps of Eucalyptus dunnii species donated by the Institute of Research and Forest Studies (IPEF).

For the elongation phase, shoots produced in the in vitro multiplication phase were prepared by isolating four $0.5 \mathrm{~cm}$ standard shoots and inoculated under aseptic conditions in glass vials ( $250 \mathrm{~mL}$ capacity) grown for 30 days, containing $50 \mathrm{~mL}$ of MS medium (Murashige and Skoog, 1962), added with $6 \mathrm{~g} \cdot \mathrm{L}^{-1}$ agar, $0.05 \mathrm{mg} \cdot \mathrm{L}^{-1}$ BAP (6-benzylaminopurine - Sigma Co.), and $0.5 \mathrm{mg} \cdot \mathrm{L}^{-1}$ of indole-3-butyric acid (IBA) (Sigma ${ }^{\circledR}$ ) (Trueman et al., 20I8).

In vitro rooting, microcuttings with size about 2 $\mathrm{cm}$, were prepared from elongated buds in the in vitro elongation phase. Microcuttings were inoculated under aseptic conditions, cultured for 30 days in glass vials (250 $\mathrm{mL}$ ) containing $50 \mathrm{~mL}$ of $\mathrm{MS}$ medium, with the addition of $6 \mathrm{~g} \cdot \mathrm{L}^{-1}$ agar, I $\mathrm{mg} \cdot \mathrm{L}^{-1} \mathrm{IBA}$ and $0.5 \mathrm{mg} \cdot \mathrm{L}^{-1}$ of naphthalene acetic acid (NAA).

The culture medium was prepared using deionized water, and its $\mathrm{pH}$ was adjusted to $5.8 \pm 0.05$ with $\mathrm{NaOH}$ (0.I M) and $\mathrm{HCl}(0.1 \mathrm{M})$ prior to autoclaving and agar addition. Autoclaving of the culture medium was performed at a temperature of $127^{\circ} \mathrm{C}$ and a pressure of approximately $1.5 \mathrm{~kg} \cdot \mathrm{cm}^{-2}$ for $20 \mathrm{~min}$. The treatments were kept in a growth room at $25 \pm 1{ }^{\circ} \mathrm{C}$ for a photoperiod of $16 \mathrm{~h}$ light and irradiance of $40 \mu \mathrm{mol} \mathrm{m} \cdot \mathrm{m}^{-1} \cdot \mathrm{s}^{-1}$ (quantified by radiometer, LI-COR ${ }^{\circledR}$, LI-250A Light Meter).

\section{DESIGN AND EXPERIMENTAL EVALUATIONS}

To evaluate packaging and sucrose variations in in vitro elongation, the experiment was organized in a $3 \times 4$ factorial arrangements, with three types of sealing: rigid polypropylene lids without membrane $(0 / M)$, polypropylene lids with a hole $(\mathrm{I} \mathrm{cm}$ in diameter) covered with a membrane of $1.0 \mathrm{~cm}^{2}(\mathrm{I} / \mathrm{M})$, polypropylene lids with three holes $(1.0 \mathrm{~cm}$ in diameter each) covered with a membrane of $1.0 \mathrm{~cm}^{2}(3 / \mathrm{M})$, and under four different sucrose concentrations $\left(0,10,20\right.$ and $\left.30 \mathrm{~g} \cdot \mathrm{L}^{-1}\right)$.

As for the experiment in the in vitro rooting phase, $3 \times 4$ factorial arrangements were used, with three sealing forms: rigid polypropylene lids without membrane $(0 / M)$, polypropylene lids with a hole $(1 \mathrm{~cm}$ in diameter) covered with a membrane of $1.0 \mathrm{~cm}^{2}(\mathrm{I} / \mathrm{M})$, polypropylene lids with four holes $(1.0 \mathrm{~cm}$ in diameter each) covered with a membrane of $1.0 \mathrm{~cm}^{2}(3 / \mathrm{M})$, and three sucrose concentrations $\left(0,10,20\right.$ and $\left.30 \mathrm{~g} \cdot \mathrm{L}^{-1}\right)$. The natural ventilation systems were obtained by porous membranes manufactured in the lids of the culture vessels, as those in Saldanha et al. $(20 / 2)$. 
For all experiments, a completely randomized design with thirty replicates, composed of a split-plot with one explant, was used. After the inoculation in the in vitro elongation phase, the following parameters were evaluated: oxidation and vigor (Figure I), shoot length $(>0.5 \mathrm{~cm})$, mean shoot number per explant $(>0.5 \mathrm{~cm})$, photosynthetic pigment, leaf area, and anatomy.

Leaf area was measured using WinFOLIATM software by the EPSON PERFECTION V700 PHOTO scanner. Five explants from each treatment were used. In each seedling, one area was evaluated and a leaf was removed from the second pair, counted from the apex of the aerial part to the root.

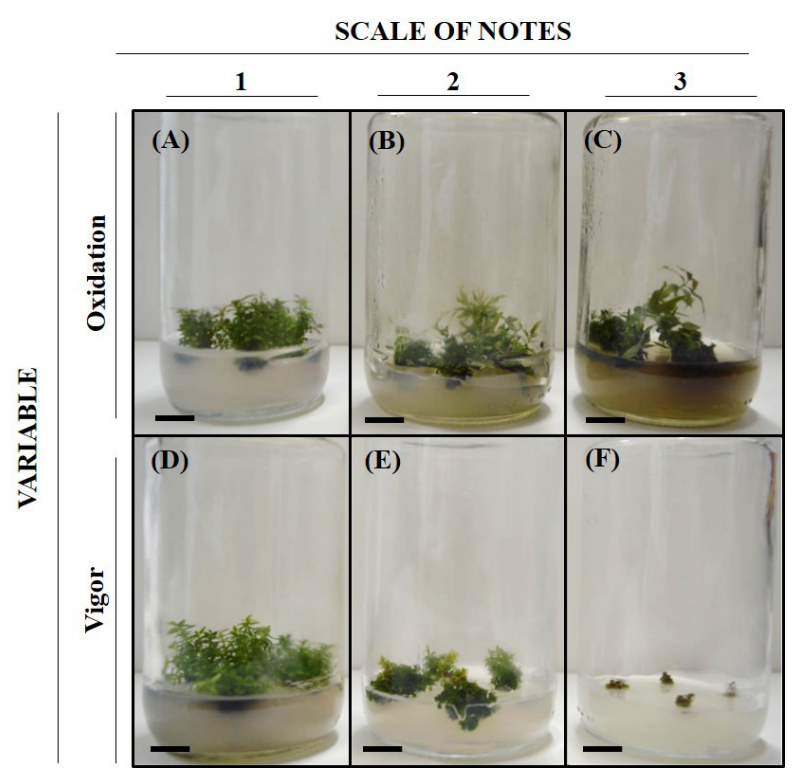

FIGURE I Oxidation and vigor assessments according to a scale of notes. (A) I = Null: no oxidation; (B) 2 = Average: reduced oxidation at the base of the explants (medium with grayish tonality; (C) $3=$ High: complete oxidation of shoots); (D) I = Optimum: induction of shoots with active growth, without apparent nutritional deficiency; (E) 2 = Good: induction of shoots, but with leaves of reduced size; $(F) 3=$ Low: no induction of shoots and, senescence and death). $\mathrm{Bar}=\mathrm{I} \mathrm{cm}$.

The length of adventitious root was assessed at 30 days (roots observed at the lower end of the vial), as well as the root number from the base of the stem, diameter and length of the largest root $(\mathrm{cm})$.

\section{Photosynthetic pigment analysis}

Once the in vitro elongation culture (30 days) under different forms of sealing and sucrose concentrations was over, leaf discs ( $25 \mathrm{mg}$ of fresh leaf matter) were withdrawn and inoculated into $5 \mathrm{~mL}$ of DMSO solution (Sigma aldrich) for 48 hours in the dark (Lichtenthaler, 1987). Sample absorbance was determined by triplicate in a $10 \mathrm{~mm}$ quartz cuvette of optical path in a Genesys I UUV spectrophotometer (ThermoScientific, USA). The wavelengths $(665,649$ and $480 \mathrm{~nm}$ ) and the equations for calculating chlorophyll concentrations $\mathrm{a}, \mathrm{b}$, and total carotenoids were based on the method described by Wellburn (1994).

\section{Leaf anatomy}

To perform the histological sections, leaves collected from each treatment were maintained in a $70 \%$ solution of formaldehyde acetic acid for 48 hours, and then the material was transferred to $70 \%$ ethanol (Johansen, 1940). The plant material was dehydrated in an alcoholic-ethylic series in increasing concentrations (80, 90 and $100 \%)$ for 30 minutes in each solution (Johansen, 1940), and it was finally stored in 100\% alcohol and histresin solution (Leica ${ }^{\circledR}$ ) in a $1: 1$ ratio in a hot oven (overnight). The embedding was with pure hydroxyethyl methacrylate resin and the cross sections obtained with the manual rotary microtome and knife with a thickness of $7 \mu \mathrm{m}$. They were then stained with toluidine blue, mounted on histological slides with stained glass finisher (Paiva et al., 2006) and photomicrographs with a coupled digital camera (AxionCam ERc5s) in a 20x and $40 x$ objective micrometer scale.

Data analysis

Data were processed in $\mathrm{R}$ Software, version 3.0.3 (R CORE TEAM, 2018), with the help of the ExpDes package, version I.I.2 (Ferreira et al., 20I3). Treatment means were used to perform the statistical analyses and adjustments of regression equations. Non-parametric variables assessed with a $5 \%$ significance test were transformed into arsenic. For the significant variables, Tukey's test was done at $5 \%$ of significance.

\section{RESULTS AND DISCUSSION}

\section{Mixotrophism effect on in vitro elongation}

Variations according to studied characteristics, different types of sealing and sucrose concentrations used on in vitro elongation were observed at 30 days of culture with the clone of Eucalyptus dunnii (Figure 3). Shoot length, number of shoots per explant and leaf area observed on in vitro elongation showed significant interaction $(p<0.05)$ (packaging and sucrose). Oxidation, explants vigor, and pigment content were factors that acted independently. The regression curves showed polynomial behavior of the second degree. 
Shoot length showed the same behavior as the number of shoots per explant and leaf area regarding sucrose concentrations, where treatment with $10 \mathrm{~g} \cdot \mathrm{L}^{-1}$ achieved the best results (Figures $2 \mathrm{~A}, 2 \mathrm{~B}$, and $2 \mathrm{I}$ ). The number of shoots per explant I/M (on average 6.15) (Figure 2B) was higher with $3 / M$ (average $3.68 \mathrm{~cm}$ ) shoots (Figure 2A), and leaf area $3 / \mathrm{M}$ (on average $7.01 \mathrm{~cm}^{2}$ ) (Figure 2l). Costa et al. (20I7), working with Ochroma pyramidale, verified similar results, obtaining higher averages for length, number of shoots per explant and leaf area using the concentration of $10 \mathrm{~g} \cdot \mathrm{L}^{-1}$ of sucrose. Silva et al. (20I7) report their positive effect on different species, which benefits cultivation and reduces costs, and can be applied to Eucalyptus dunnii.

However, in vitro propagation with the use of porous membranes allows the exchange of gases between the external and internal atmosphere of the flasks through natural ventilation, provided that the concentration of $\mathrm{CO}_{2}$ is adequate, resulting in increased growth (Kozai, 20I0; Martins et al., 20I5). In Capsicum annuum, Batista et al. (2017) verified higher shoot length and number of leaves per explant in membrane system when compared to conventional system. For Vaccinium ashei Reade, the membrane-based system provided higher shoot length, number of shoots, leaf area and chlorophyll content (Hung et al., 20I6).

Oxidation evaluations according to grade scale evidenced lowest averages without sucrose supplementation (I.2I) (Figure 2D) and S/M (Figure 2C), but no difference was observed otherwise $(p>0,05)$. In vitro conditions are stressful to plant growth, and high concentrations of exogenous sugar are a major cause of oxidation during in vitro culture (Tisarum et al., 20I8).

In contrast, the concentration of $30 \mathrm{gL}^{-1}$ sucrose (mean 2.85) (Figure 2F) and 3/M (Figure 2E), although not statistically different $(>0.05)$, stands out. For Alocasia amazonica, according to Jo et al. (2009), the concentration of $30 \mathrm{~g} \cdot \mathrm{L}^{-1}$ of sucrose achieved the best results in the morphophysiological aspects and also in explants development.

However, desired results with membrane use may be associated with increased photosynthesis caused by high $\mathrm{CO}_{2}$ availability. The in vitro culture of Plectranthus amboinicus, an improvement in explant vigor was observed with the use of three membranes in the containers (Silva et al., 20I7).

Best results regarding pigment content were obtained with the use of membranes (Figure 2G) and 20 $\mathrm{g} \cdot \mathrm{L}^{-1}$ sucrose (Figure $2 \mathrm{H}$ ), evidencing the importance of greater gas exchange $\left(\mathrm{CO}_{2}\right)$, and an external carbohydrate source in plant growth under these conditions. Sucrose levels had an effect on shoot regeneration and bioactive compounds content in Ajuga multiflora (Jeong and Sevanesan, 2018). According to Yuan et al. (2015), the biosynthesis of chlorophyll and carotenoids is also regulated by gas exchange and sucrose. Prolonged exposure to high concentrations of exogenously applied sucrose in most plants may result in an inhibition of photosynthesis, which is associated with inhibition of chlorophyll biosynthesis (McCarthy et al., 2016).
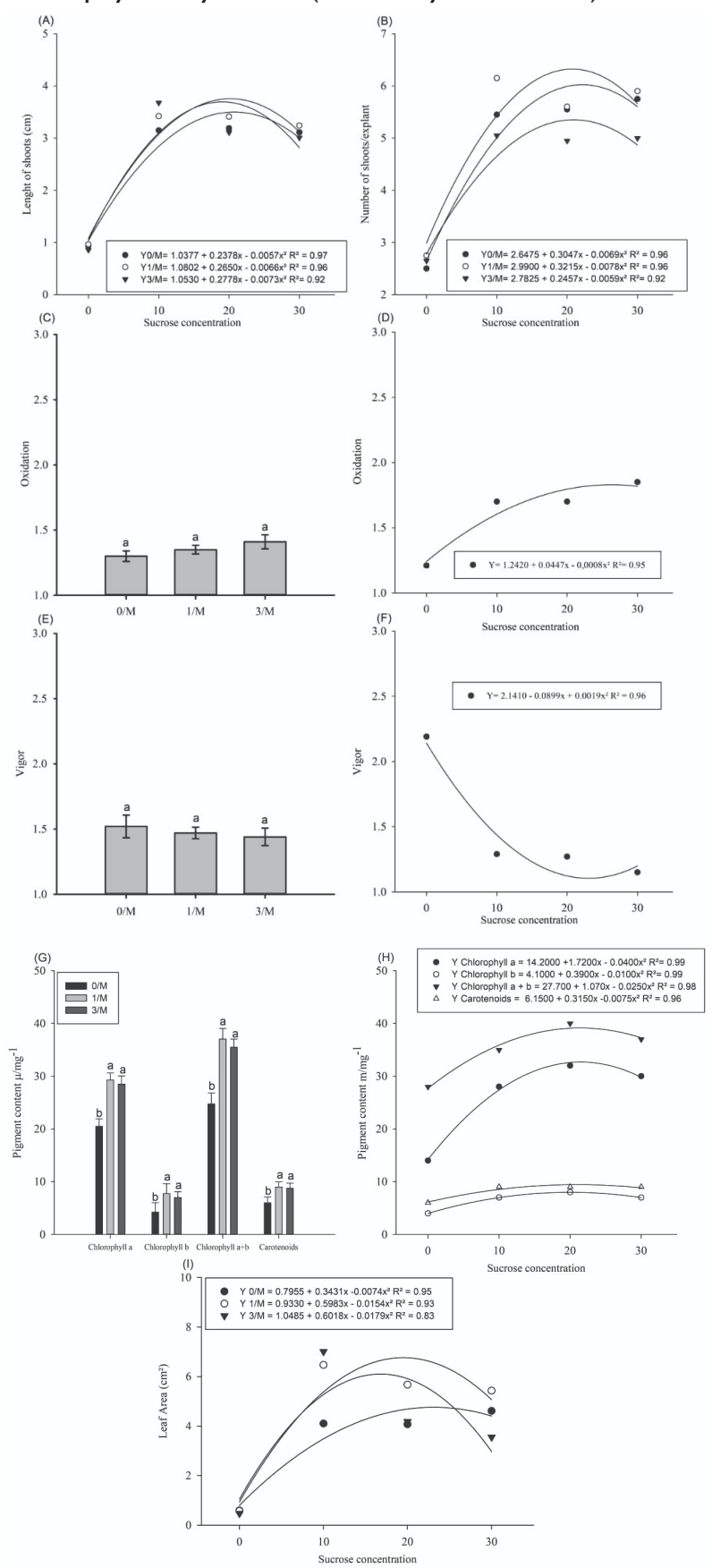

FIGURE 2 Characteristics observed on in vitro elongation of Eucalyptus dunnii regarding different sealing $(0 / \mathrm{M}$, $\mathrm{I} / \mathrm{M}$ and $3 / \mathrm{M})$ and sucrose concentrations $(0,10,20$ and $\left.30 \mathrm{~g} \cdot \mathrm{L}^{-1}\right)$. (A) Shoot length; (B) Number of shoots per explant; (C and D) Shoot oxidation; (E and F) Shoots vigor; (G and H) Pigment content; (I) Leaf area. *Averages followed by the same letter do not differ from each other, by Tukey's test at 5\% probability. 
Results report several effects of membrane use on plants grown in vitro, such as improved growth and increased content of photosynthetic pigments, mainly by maintaining adequate concentrations of $\mathrm{CO}_{2}$ to stimulate photosynthesis (Saldanha et al., 20 I 2). Bandeira et al. (2007) studies with the species Thymus vulgaris and Saldanha et al. (20I2) with Pfaffia glomerata, this system improved the in vitro growth and increased the photosynthetic pigment content of the seedlings compared to the conventional system. Rodrigues et al. (2012) verified a lower number of shoots, photosynthetic pigment content and increased senescence in conventional system, in the Azadirachta indica species when comparing membrane use.

The use of the membrane system and sucrose concentration (10 g. $\left.\mathrm{L}^{-1}\right)$ was directly implicated on in vitro elongation of Eucalyptus dunnii, being determinant for shoot length, number of shoots per explant, pigment content and leaf area, where a reduction of this component in the medium is evidenced, since the most used in the micropropagation of Eucalyptus is $30 \mathrm{~g} \cdot \mathrm{L}^{-1}$ (Brondani et al., 20I2). The lack of carbohydrate source in the culture medium showed the worst results in length, number, vigor, leaf area, and pigment content. In vitro culture plants partially lose autotrophism and, consequently, need an exogenous source of carbohydrates, being the most used sucrose in plant tissue culture (Parveen and Shahzad, 20I4).

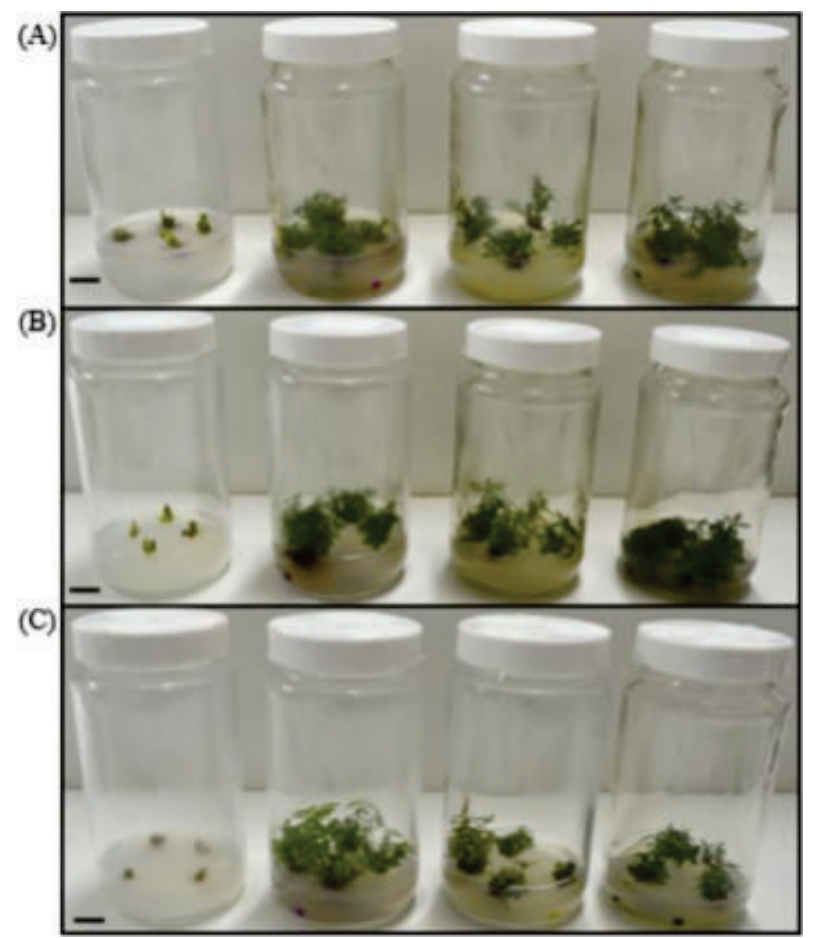

FIGURE 3 Explants of the clone of Eucalyptus dunnii at 30 days in the in vitro elongation phase. (A) Without a membrane (O/M); (B) With a membrane (I/M); (C) With three membranes $(3 / M)$. * From left to right $(0,10,20$ and $30 \mathrm{~g} \cdot \mathrm{L}^{-1}$ sucrose) Bar $=1 \mathrm{~cm}$..
Anatomical structure of the foliar cells can also be influenced by the packaging system of the containers used on in vitro culture. The literature reports that the natural ventilation system, for instance, makes leaf cells more organized and consequently they form more rustic leaves. As stated by Silva et al. (2014), natural ventilation provided an increase in the thickness of Cattleya walkeriana leaf mesophyll and stomata, making them more functional. Mohamed and Alsadon (2010) evaluated the anatomy of potato seedlings cultured in vitro, and found that the use of natural ventilation resulted in thicker leaves with more developed xylem than the conventional system. Results from this study show that membrane-sealing systems provided more developed vascular bundles (Fig. 4A to $4 \mathrm{C}$ ) and reduced intercellular spaces of mesophyll cells (Figure 4D to 4F).

\section{Mixotrophic effect on in vitro rooting}

Length, number of shoots, and root diameter acted independently regarding sealing, in face of the sucrose concentrations. These factors were significant $(p<0.05)$ for adventitious rooting. Regression curves showed polynomial behavior of the second degree.

At 30 days on in vitro rooting phase, sealing and sucrose concentration showed the same tendency, with the best results obtained for the treatment with $\mathrm{I} / \mathrm{M}$ and $30 \mathrm{~g} \cdot \mathrm{L}^{-1}$ (Figure 5), due to length (Fig. 6A and 6B), shoot number per explant averaging 1.70 and 1.98 (Figure 6C and 6D), and mean root diameter of 0.17 and $0.28 \mathrm{~cm}$ (Figure 6E and 6F). In Vaccinium ashei, the ventilation system provided greater length and number of roots (Hung et al., 2016). The use of systems that increase the $\mathrm{CO}_{2}$ supply to in vitro plants are conditions that can increase plant growth, improve physiological characteristics and facilitate seedlings acclimatization to ex vitro conditions, promoting the development of the photosynthetic apparatus (Shin et al., 20l4).

Adventitious rooting is a challenge in clonal propagation, with variations from 4 to $46.5 \%$ (Brondani et al., 20II; Obserschelp et al., 20I5). However, for Eucalyptus dunnii, it found a better response to rooting with $66.66 \%$ using $\mathrm{I} / \mathrm{M}$ and $30 \mathrm{~g} \mathrm{~L}^{-1}$ sucrose (Figure $5 \mathrm{G}$ ). The increase in $\mathrm{CO}_{2}$ concentration promotes rooting and reduces growth anomalies, as it may improve the photosynthetic rate (Cha-Um et al., 20ll). This condition is related to the reduction of water loss due to the deposition of epicuticular wax and to the production of functional stomata (Martins et al., 20I5; Hoang et al., 20I7). According to Moreira et al. (20I3), the effects of the use of membranes to increase the gas exchange infer 


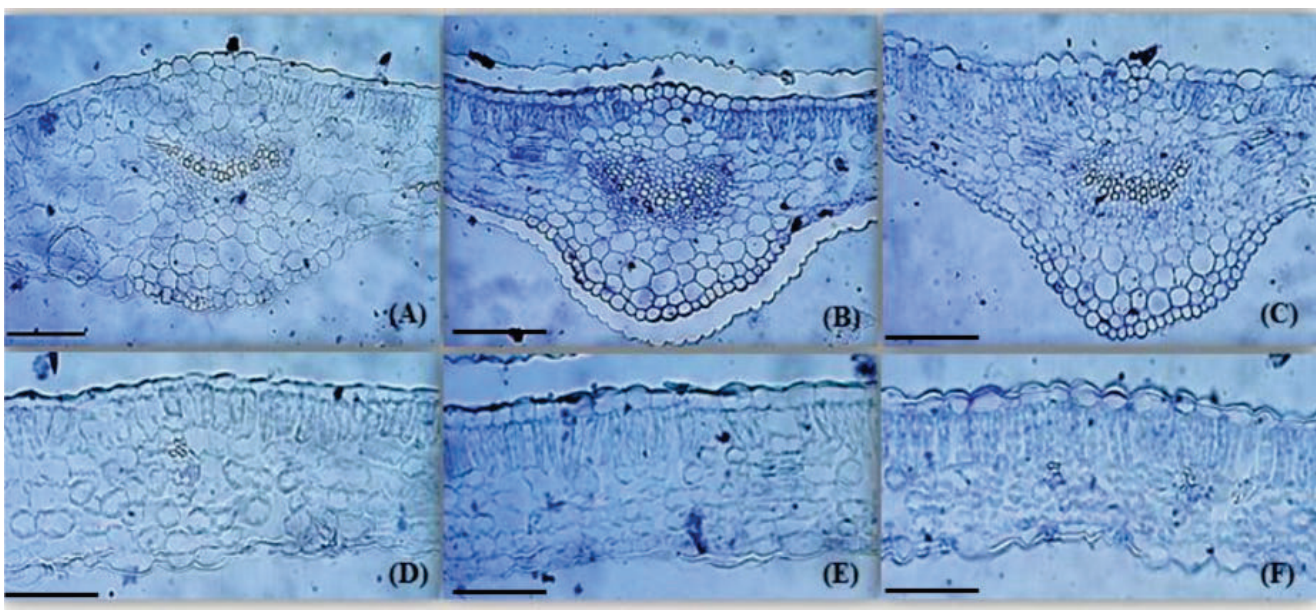

FIGURE 4 Cross sections of the central rib and leaf blade of Eucalyptus dunnii as a function of different sealing systems and $30 \mathrm{~g} \cdot \mathrm{L}^{-1}$ sucrose. (A and D) Without a membrane (0/M); (B and E) With a membrane (I/M); (C and F) With three membranes (3/M). Bar = $100 \mu \mathrm{m}$.

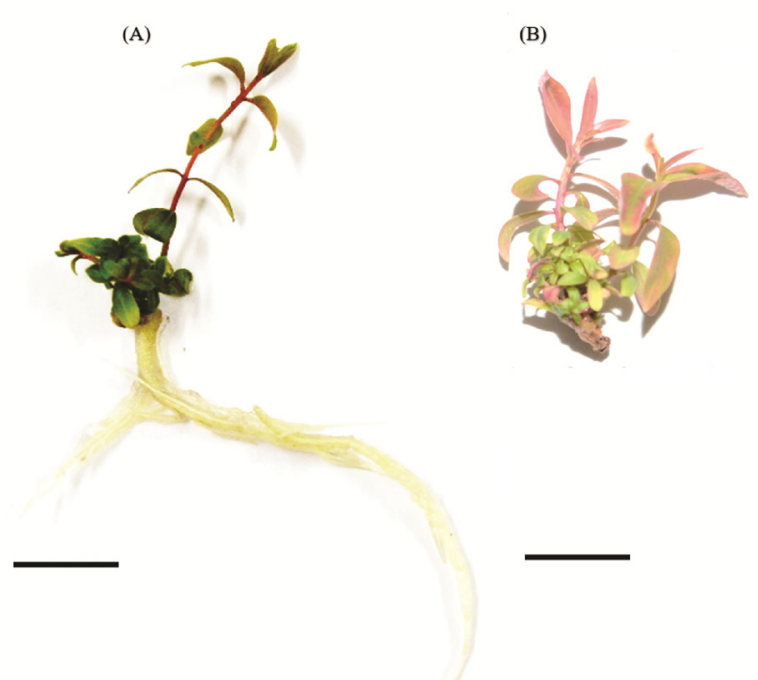

FIGURE 5 Explants of the clone of Eucalyptus dunnii at 30 days in the in vitro rooting phase in the treatment with a membrane $(\mathrm{I} / \mathrm{M})$ and $30 \mathrm{~g} \cdot \mathrm{L}^{-1}$ of sucrose. (A) Rooted explant; (B) Explant without root. Bar = I cm..

in the reduction of relative humidity, increase of aeration, production of more rustic plants and, as a consequence, greater survival and rooting. The use of sucrose was also considered paramount. Using bioreactors in Populus hybrids, sucrose provided higher percentages of survival and rooting when compared without the carbon source (Arencibia et al., 2017).

In contrast to the aforementioned results, for in vitro cultivation and ex vitro acclimatization of Hevea brasiliensis, better results for root length and number, survival and rooting were obtained without sucrose and flasks that allowed natural ventilation (Tisarum et al., 2018). Sometimes gradual adaptation to the ex vitro condition may be required for plants grown in in vitro mixotrophic systems to undergo autotrophic growth in greenhouse (Perez et al., 2015).
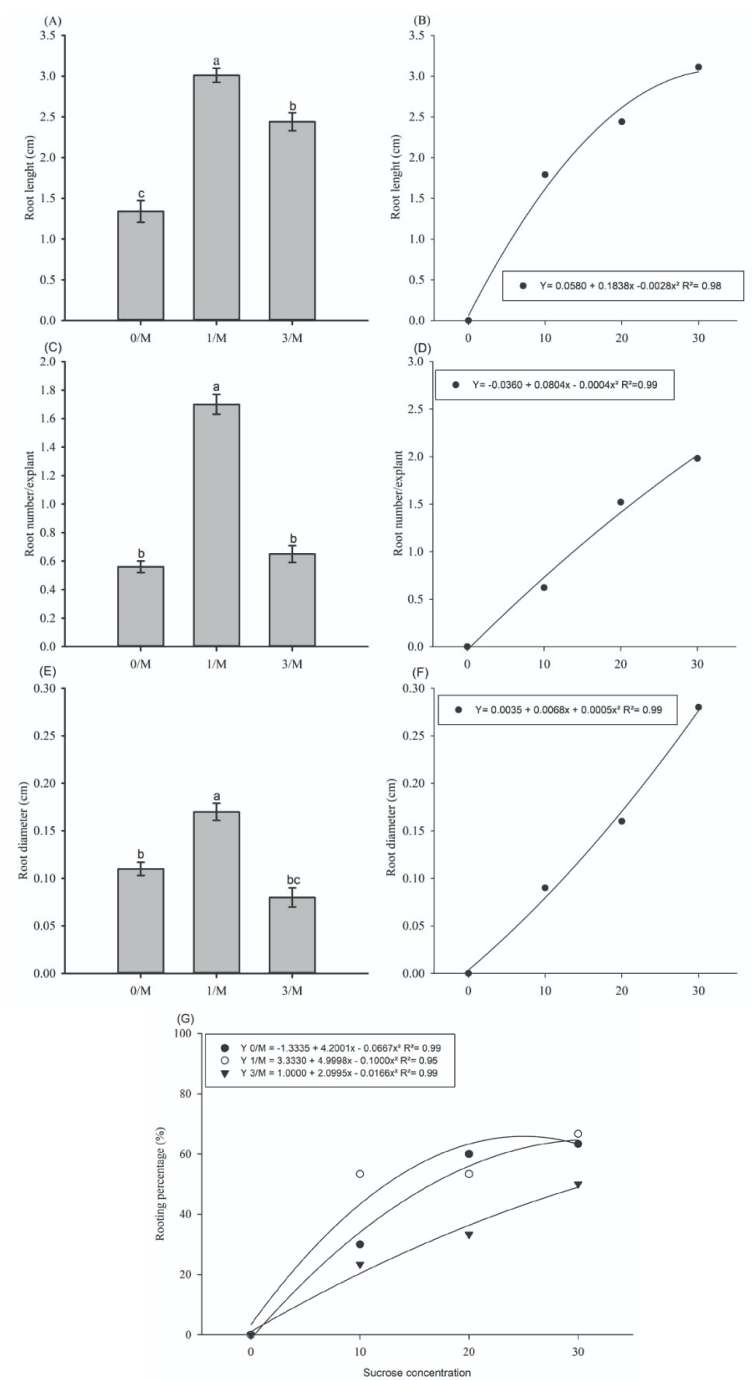

FIGURE 6 Characteristics observed in the in vitro rooting of Eucalyptus dunnii as a function of different sealing $(0 / \mathrm{M}, 9 / \mathrm{M}$ and $3 / \mathrm{M})$ and sucrose concentrations $\left(0,10,20\right.$ and $\left.30 \mathrm{~g} \cdot \mathrm{L}^{-1}\right)$. (A and $B$ ) Root length; ( $C$ and $D$ ) Number of roots per explant; ( $E$ and F) Root diameter; (G) Rooting percentage. *Averages followed by the same letter do not differ from each other, by Tukey's test at $5 \%$ probability. 


\section{CONCLUSIONS}

Sucrose should be added on in vitro culture medium for the elongation of Eucalyptus dunnii clones, which may be reduced to concentrations between 10 and $20 \mathrm{~g} \cdot \mathrm{L}^{-1}$.

The use of flasks with membranes that allow higher gas exchange is an effective alternative to improve in vitro elongation and adventitious rooting.

The concentration of $30 \mathrm{~g} \cdot \mathrm{L}^{-1}$ sucrose should be added in the culture medium for in vitro adventitious rooting in Eucalyptus dunnii.

Absence of carbohydrate was ineffective for the in vitro elongation and adventitious rooting of Eucalyptus dunnii.

\section{REFERENCES}

ARENCIBIA, A.D.; GÓMEZ, A.; POBLETE, M.; VERGARA, C. High performance micropropagation of dendroenergetic poplar hybrids in photomixotrophic temporary immersion bioreactors (TIBs). Industrial Crops and Products, v. 96, p.102-109, 2017.

BACCARIN, F.J.B.; BRONDANI, G.E.; ALMEIDA, L.V.; VIEIRA, I.G.; OLIVEIRA, L.S.; ALMEIDA, M. Vegetative rescue and cloning of Eucalyptus benthamii selected adult trees. New Forests, v.46, p. 465-483, 2015.

BANDEIRA, J.M.; LIMA, C.S.M.; RUBIN, S.; RIBEIRO, M.V.; FALQUETO, A.R.; PETERS, J.Á. Diferentes tipos de vedações dos frascos e concentrações de sacarose na micropropagação de Thymus vulgaris L. Revista Brasileira de Biociências, v. 5, n. 2, p. 472-474, 2007.

BATISTA, D.S.; DIAS, L.L.C.; RÊGO, M.M. DO; SALDANHA, C.W.; OTONI, W.C. Flask sealing on in vitro seed germination and morphogenesis of two types of ornamental pepper explants. Ciência Rural, v. 47, n. 3, p. I-6, 2017.

BATISTA, D.S.; FELIPE, S.H.S.; SILVA, T.D.; CASTRO, K.M.; RODRIGUES, T.C.M.; MIRANDA, N.A. Light quality in plant tissue culture: does it matter. In Vitro Cellular and Developmental Biology - Plant, v. 54, n. 3, p. 195-215, 2018.

BIANCHETTI, R.E.; RESENDE, C.F.de; PACHECO, V.S.; DORNELLAS, F.F.; OLIVEIRA, A.M.S. de; FREITAS, J.C.E.; PEIXOTO, P.H.P. An improved protocol for in vitro propagation of the medicinal plant Mimosa pudica L . African Journal of Biotechnology, v. 16, n. 9, p. 418-428, 2017.

BRONDANI, G.E.; DUTRA, L.F.; WENDLING, I.; GROSSI, F.; HANSEL, F.A.; ARAUJO, M.A. Micropropagation of an Eucalyptus hybrid (Eucalyptus benthamii $\times$ Eucalyptus dunnii). Acta Scientiarum. Agronomy, v. 33, n. 4, p. $655-63,2011$.

BRONDANI, G.E.; WIT ONDA, H.W.de; BACCARIN, F.J.B.; GONÇALVES, A.N.; ALMEIDA, M. de. Micropropagation of Eucalyptus benthamii to form a clonal micro-garden. In Vitro Cellular Developmental Biology - Plant, v. 48, n. 5, p. 478-487, 2012.
BRONDANI, G.E.; OLIVEIRA, L.S.de;, KONZEN, E.R.; SILVA, A.L.L. da; COSTA, J.L. Mini-incubators improve the adventitious rooting performance of Corymbia and Eucalyptus microcuttings according to the environment in which they are conditioned. Anais da Academia Brasileira de Ciências, v. 90, p. 2409-2423, 2018.

CHA-UM, S.; CHANSEETIS, C.; CHINTAKOVID, W.; PICHAKUM, A.; SUPAIBULWATANA, K. Promoting root induction and growth of in vitro macadamia (Macadamia tetraphylla L. 'Keaau') plantlets using $\mathrm{CO}_{2}$-enriched photoautotrophic conditions. Plant Cell, Tissue and Organ Culture, v. 106, n.3, p.435 - 444, 201 I.

COSTA, M.B.T.; ARRUDA, A.S.; VIEIRA, M.C.; PAULA, M.S.P.; LUZ, J.P. Estabelecimento in vitro de Ochroma pyramidale em diferentes concentrações de meio MS e sacarose. Revista Agrotecnologia, v. 8, p. I-9, 2017.

FERREIRA, E.B.; CAVALCANTI, P.P; NOGUEIRA, D.A. ExpDes: Experimental Designs package. $R$ package version I.I.2. 2013.

HERINGER, A. S.; REIS, R. S.; PASSAMANI, L. Z.; SOUZAFILHO, G. A.; SANTA-CATARINA, C.; SILVEIRA, V. Comparative proteomics analysis of the effect of combined red and blue lights on sugarcane somatic embryogenesis. Acta Physiologiae Plantarum, v.39, p. 39-52, 2017.

HOANG, N.N.; KITAYA, Y.; MORISHITA, T.;ENDO, R.;SHIBUYA, T. A comparative study on growth and morphology of wasabi plantlets under the influence of the micro-environment in shoot and root zones during photoautotrophic and photomixotrophic micropropagation. Plant Cell, Tissue and Organ Culture, v. I30, n. 2, p. 255-263, 2017.

HUNG, C.D.; HONG, C.H.; KIM, S.K.; LEE, K.H.; PARK, J.Y.; DUNG, C.D.; NAN, M.W.; LEE, H.I. In vitro proliferation and ex vitro rooting of microshoots of commercially important rabbiteye blueberry (Vaccinium ashei Reade) using spectral lights. Scientia Horticulturae, v. 2II, p. 248-254, 2016.

JEONG, B.R.; SIVANESAN, I. Impact of light quality and sucrose on adventitious shoot regeneration and bioactive compound accumulation in Ajuga multiflora Bunge. Scientia Horticulturae, v. 236, p. 222-228, 2018.

JOHANSEN, D.A. Plant microtechnique. London: McGrawHill Book Company, 1940, 510p.

JO, E.A.; TEWARI, R.K.; HAHN, E.J.; PAEK, K.Y. In vitro sucrose concentration effects growth and acclimatization of Alocasia amazonica plantlets. Plant Cell, Tissue and Organ Culture, v. 96, p. 307-315, 2009.

KOZAI, T. Photoautotrophic micropropagation. Environmental control for promoting photosynthesis. Propagation of Ornamental Plants, v. 10, p. 188-204, 2010.

KRAUS, J.E.; ARDUIN, M. Manual básico de métodos em morfologia vegetal. Seropédica, RJ: EDUR, 1997, 198p. 
LICHTENTHALER, H.K. ChlorolShylls and carotenoids: pigments of photosynthetic biomembranes. Methods in Enzymology, v. I48, p. 350-382, 1987.

MARTINS, J.P.R.; PASQUAL, M.; MARTINS, A.D.; RIBEIRA, S.F. Effects of salts and sucrose concentrations on in vitro propagation of Billbergia zebrina (Herbert) Lindley (Bromeliaceae). Australian Journal of Crop Science, v. 9, n. I, p. 85-9I, 2015.

MCCARTHY, A.; CHUNG, M.; IVANOV, A.G.; KROL, M.; INMAN, M.; MAXWELL, D.P. An established Arabidopsis thaliana var. Landsberg erecta cell suspension culture accumulates chlorophyll and exhibits a staygreen phenotype in response to high external sucrose concentrations. Journal of Plant Physiology, v. 199, p. 40-5I, 2016.

MOHAMED, M.A.; ALSADON, A.A. Influence of ventilation and sucrose on growth and leaf anatomy of micropropagated potato plantlets. Scientia Horticulturae, v. 123, p. 295 300,2010

MOREIRA, A.L.; SILVA, A.B.; SANTOS, A.; REIS, C.O.; LANDGRAF, P.R.C. Crescimento de Cattleya walkeriana em diferentes sistemas de micropropagação. Ciência Rural, v. 43 , n. 10, p. 1804-1810, 2013.

MURASHIGE, T.; SKOOG, F. A revised medium for rapid growth and bioassays with tobacco tissue cultures. Physiologia Plantarum, v. 15, p. 473-497, 1962.

NAVROSKI, M.C.; REINIGER, L.R.S.; PEREIRA, M.O Alongamento in vitro de rebentos de Eucalyptus dunnii em função de diferentes genótipos e concentrações de ácido I-naftil-acético (ANA). Revista de Ciências Agrárias, v. 38, n. I, p. 79-86, 2015

OBERSCHELP, G.P.J.; GONCALVES, A.N.; MENEGHETTI, E.C.; GRANER, É.; ALMEIDA, M.de. Eucalyptus dunnii Maiden plant regeneration via shoot organogenesis on a new basal medium based on the mineral composition of young stump shoots. In Vitro Cellular and Developmental Biology - Plant, v. 5I, p. 626-636, 2015.

PAIVA, J.G.A.de; FANK DE CARVALHO, S.M.; MAGALHÃES, M.P.;RIBEIRO, D.G. Verniz vitral incolor $500 \AA$ : uma alternativa de meio de montagem economicamente viável. Acta Botânica Brasileira, v. 20, n. 2, p. 257-264, 2006.

PARVEEN, S.; SHAHZAD, A. Factors affecting in vitro plant regeneration from cotyledonary node explant of Senna sophera (L.) Roxb. - A highly medicinal legume. African Journal of Biotechnology, v. I3, p. 4I3-422, 20 I4.

PÉREZ- JIMÉNEZ, M.; LÓPEZ-PÉREZ, A.; OTÁLORAALCÓN, G.; MARIN-NICOLÁS, D.; PINERO, M.C. AMOR, F.M. A regime of high $\mathrm{CO}_{2}$ concentration improves the acclimatization process and increases plant quality and survival. Plant Cell, Tissue and Organ Culture, v. 121 , p. 547-557, 2015.
RODRIGUES, M.; COSTA, T.H.F.; FESTUCCI-BUSELLI, R.A.; SILVA, L.C.; OTONI, W.C. Effects of flask sealing and growth regulators on in vitro propagation of neen (Azadirachta indica A.Juss.). In Vitro Cellular Developmental Biology - Plant, v. 48, n. I, p. 67-72, 2012.

SALDANHA, C.W.; OTONI, C.G.; AZEVEDO, J.L.F.de; DIAS, L.L.C.; REGO, M.M.do; OTONI, W.C. A low-cost alternative membrane system that promotes growth in nodal cultures of Brazilian ginseng [Pfaffia glomerata (Spreng) Pedersen]. Plant Cell, Tissue and Organ Culture, v. II0, p. 4I3-422, 2012.

SILVA, A.B.; LIMA, P.P.; OLIVEIRA, L.E.S.; MOREIRA, A.L. In vitro growth and leaf anatomy of Cattleya walkeriana (Gardner, 1839) grown in natural ventilation system. Revista Ceres, v.6I, n. 6, p. 883-890, 2014.

SILVA, J.A.T.D.; HOSSAIN, M.M.; SHARMA, M.; DOBRÁNSZKI, J.; CARDOSO, J.C.; SONGJUN, Z.E.N.G. Acclimatization of in vitro-derived Dendrobium. Horticultural Plant Journal, v. 3, n. 3, p. II0-124, 2017.

SHIN, K.S.; PARK, S.Y.; PAEK, K.Y. Physiological and biochemical changes during acclimatization in a Doritaenopsis hybrid cultivated in different microenvironments in vitro. Environmental and Experimental Botany, v. 100, p. 26-33, 2014.

SMITH, H.J.; HENSON, M. Achievements in forest tree genetic improvement in Australia and New Zealand: Tree improvement of Eucalyptus dunnii Maiden Achieve. Australian Forestry, v. 70, n. I, p. 17-22, 2007.

TISARUM, R.; SAMPHUMPHUNG, T.; THEERAWITAYA, C.; PROMMEE, W.; CHA, S. In vitro photoautotrophic acclimatization direct transplantation and ex vitro adaptation of rubber tree (Hevea brasiliensis). Plant Cell, Tissue and Organ Culture, v. I33, n. 2, p. $215-$ 230, 2018

TRUEMAN, S.J.; HUNG, C.D.; WENDLING, I. Tissue culture of Corymbia and Eucalyptus. Forests, v. 9, n. 2, p. I-42, 2018.

WELLBURN, A.R. The spectral determination of chlorophylls $a$ and $b$ as well as total carotenoids, using various solvents with spectrophotometers of different resolution. Journal of Plant Physiology, v. I44, n. 3, p. 307-3 I3, 1994

XAVIER, A.; WENDLING, I.; SILVA, R.L.DA. Silvicultura clonal: princípios e técnicas. $2^{\circ}$. ed. Viçosa, MG: Ed. UFV, 2013, 272p.

YUAN, H.; ZHANG, J.; NAGESWARAN, D.; LI, L. Carotenoid metabolism and regulation in horticultural crops. Horticulture Research, v. 2, n. I5036, p. I II, 2015. 